\title{
Correction to: Inequality and Innovation: Barriers and Facilitators to 17P Administration to Prevent Preterm Birth among Medicaid Participants
}

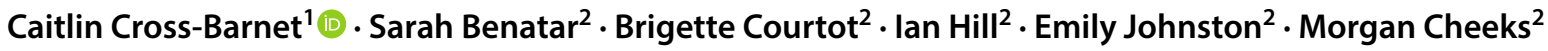

Published online: 30 November 2018

(c) Springer Science+Business Media, LLC, part of Springer Nature 2018

\section{Correction to: \\ Maternal and Child Health Journal (2018) 22:1607-1616 \\ https://doi.org/10.1007/s10995-018-2556-4}

The original version of this article unfortunately contained a mistake in the order of authors. The co-author "Sarah Benatar" should be the second author and "Brigette Courtot" should be the third author of the article.

The original article can be found online at https://doi.org/10.1007/ s10995-018-2556-4.

Caitlin Cross-Barnet

caitlin.cross-barnet@cms.hhs.gov

Sarah Benatar

sbenatar@urban.org

Brigette Courtot

bcourtot@urban.org

Ian Hill

ihill@urban.org

Emily Johnston

ejohnston@urban.org

Morgan Cheeks

mcheeks@urban.org

1 Center for Medicare and Medicaid Innovation (CMMI),

7500 Security Boulevard, WB-19-72, Baltimore, MD 21244,

USA

2 Urban Institute, 2100 M St NW, Washington, DC 20037, USA 